\title{
Teaching Loyalty Within A Moral Education
}

\author{
Mary Moore \\ Indiana Central University
}

\section{Loyalty and Education: Principle and Practice}

How are values to be taught? Moral education would involve providing students with both instruction in the subject-matter of the academic disciplines as well as moral instruction. For example, a connection has been made since the early 1900 s between democracy and education. It has been argued that the possibility of a democratic state in which people participate and direct political life depends upon an educated citizenry: there needs to be an informed population before choice can be intelligently exercised. Education is credited with protecting the possibility of loyalty. It is hoped through education that a child will be protected from seeking the selfless devotion of the fanatic or terrorist or from showing the selfishness of the instrumental person who sees no greater cause than self-interest or personal freedom. Durkheim saw education as a moral enterprise in which the importance of the collective body would be affirmed. Dewey saw the educational experience as imparting moral habits that would enable a child to become self-reliant, independent, and self-directed.

The problem posed by moral education is that in order for values to be taught, they already need to be a part of the educational experience. Only a certain kind of education could impart values; only a teaching guided by a respect for values could teach values to a student. In the case of loyalty, a teacher would need a sense of the tension between the principle of loyalty, in which an ideal or standard is articulated, and the practice of loyalty in which one determines what is at stake, what are the choices, and what stand to take. If schools are to teach both the principle and practice of loyalty, then the teacher must be able to evoke the child's life as involving occasions in which loyalty must be shown or in which loyalty could be at stake. The teaching of loyalty requires the ability to evoke the host of possibilities for loyalty in the child's life.

One of the most interesting features of a teaching of loyalty which seeks to impart an understanding of loyalty itself is that there are no rules or formulas for how to act loyally. Loyalty cannot always be accomplished through a simple show of compliance or conformity. There have been those who have shown only obedience to authority, and they have been judged by their contemporaries and others as informers, traitors, or war criminals. Neither can loyalty always be shown through the practice of resistance. While those who have resisted authority have been seen as loyal figures, e.g., the loyal opposition, nevertheless the unyielding practice of resistance could be no more than defiance or obstinacy.

Can the meaning of loyalty be gained then from a reading of texts in which loyalty is discussed? The problem remains, however, as to how the reader knows that loyalty is at stake in the example chosen. For example, it may be a question as to whether or not loyalty is at stake when individuals are divided over their concern with keeping or revealing secrets: for example, the difference between the friendly and unfriendly testimonies given to the House Committee on Un-American Activities in the investigation of Hollywood. Loyalty cannot simply be studied through an examination

Phenomenology + Pedagogy Volume 1 Number 31984 
of those texts in which it is cited for loyalty must often be located in the texts by the reader given that the situation in question may not directly involve speeches about loyalty at all.

The problem of how to act loyally cannot be separated from how to know loyalty, and thus it seems that the teaching of loyalty as a value requires inquiry into what it is and how it can be located in a set of practices or as a way of orienting oneself to others.

\section{Teaching Loyalty: Attachment and the Recognition of Difference}

How could a child's life be seen as the context for practicing loyalty? What possibilities for participating in loyalty are represented by the child's life? Could the child's life be formulated as a site for knowing loyalty? One situation can be located in the child's life concerning loyalty if we formulate loyalty as the protection and defense of a relation. Conversely, knowledge of what to defend also involves knowledge of what to abandon. The situation in which loyalty would be at stake is the child's relation to the teacher.

John Dewey considered in his work the problem of the child's attachment to her teacher. Through a sustained discussion of this example we will seek to understand why loyalty is a feature of the student/teacher relation. In the following selection Dewey raises the question of what should moderate a student's attachment to the teacher:

Some stimulus must be found to keep the child at his studies. At best this will be his affection for his teacher, together with a feeling that he is not violating the school rules, and thus negatively, if not positively, is contributing to the good of the school. I have nothing to say against these motives so far as they go, but they are inadequate. The relation between the piece of work to be done and affection for a third person is external, not intrinsic. It is therefore liable to break down whenever the external conditions are changed. Moreover, this attachment to a particular person, while in a way social may become so isolated and exclusive as to be selfish in quality. (1975, p. 23)

Dewey presents this problem to his reader: some stimulus must be found to keep the child at her studies, and what should this stimulus be? On the other hand there is an attraction that the child has to the teacher and due to this affection the child seems to want to learn. However, the reader is told by Dewey that the child's attraction to the teacher is not an adequate stimulus, and another stimulus must be sought. Thus the attachment to the teacher is to be seen as extrinsic or peripheral to the more central relation which the child is to have to learning.

Consider for a moment Dewey's selection of the term "stimulus" as a characterization of the motivation that is needed for learning. As one who is stimulated, the child is depicted as a passive agent. What is the difference, for instance, between being stimulated and being inspired? While learning would be tied to that which inspires, and what is to be learned would not be differentiated from being inspired, stimulation is an action that does not figure in the process of learning. The problem remains, however, as to why the child needs a stimulus. Why does Dewey suggest a child who does not want to study, and a study that does not call to the student? Why does he suggest that the student must be kept at her studies independent of her desires? 
Dewey sees the child's need for acceptance by the teacher as a way employed by the child to motivate herself to learn. For Dewey the problem with motivating oneself through a love of the teacher is that a dependency is created. The child is dependent upon the teacher's approval as the source of her interest in learning. One question that Dewey does not ask is how it is that the child comes to present herself as needing acceptance? It would seem that the child's need for acceptance demonstrates an understanding that there is a difference between parents and the teacher. We do not think of the child as being motivated by a need for acceptance in relation to parents. Rather, family stands as a place to which a child should unproblematically belong. A child should be able to act with assurance about her place in her family, and thus to be motivated by the need for acceptance in the context of the family would suggest an unduly anxious child or withholding parents.

There is a difference between the experience of home and school for the child. The teacher may be recognized as being essentially unlike parents because the practice of teaching does not center upon the care of children. The teacher seems to assume that children are cared for at home and thus teaches in a way that assumes this care. The teacher has access to knowledge and understanding that the child would like to share or participate in, and it would seem to be the very difference between the role of the qualified and the novice that attracts the student to the teacher in the first place. The break which Dewey believes will inadvertently occur in the child's relation to the teacher can be recast as a division or difference which already exists in the idea of the teacher and the student. To be a student is to recognize the difference between the teacher and oneself as something from which one can learn.

It is also possible then that the child's need for acceptance is a positive act because it involves a recognition of the difference which is exemplified by the teacher. The need for acceptance may reflect the child's interest in belonging or including the self in a relation that is not yet understood. The need for acceptance then may reflect an interest, that is as yet a curiosity, on the part of the child.

The attachment of the student to the teacher has thus far been formulated as the child's need for the teacher's acceptance given the recognition of an essential difference between home and school. The loyalty that is felt towards the home--whether one defines the family as the home or the country as the homeland -is natural piety. Natural piety refers to how the home, what is closest to one, comes to define one's loves and duties. Natural piety is the respect that one shows for that relation to the home which has nurtured one's life. As a type of loyalty, natural piety recommends an unquestioned devotion to the defense and protection of the home.

As a plan for life, however, natural piety is inadequate because a show of unquestioned devotion does not address the problem of that good for which a life will stand. While natural piety refers to the stand that one must take to show the importance of the gift of nurturance, nevertheless, this stand is not adequate for the identification of a life as a particular kind of life: that is, as a life committed to the articulation of itself through some collective good. 
In order for loyalty to mature, it must be divided against itself. If the problem of self-identity is to be known and felt, then the adherence to natural piety as the only form of loyalty must be rejected. While natural piety dictates that the child must allow the home (what is closest to her) to define her loves and duties, nevertheless, the child must resist natural piety as a response appropriate for all other relations.

In the context of the limitation to natural piety, the child's need for acceptance within the school becomes interesting. The need for the teacher's acceptance seems to recognize an essential difference between home and school or parent and teacher. School, then, does not become a substitute or a competitor with the home; rather, school provides an alternative occasion for forming an attachment based upon choice or the commitment of oneself. School provides for an attachment that is grounded in the child's interest in what is different from herself, whereas home calls for a recognition and affirmation of sameness. If natural piety is not to become fanaticism, then the child must learn that responding to all causes with an unquestioned devotion is inappropriate. The child must learn that an unquestioned devotion to a cause other than home is a mistaken or misplaced attachment.

The concern originally expressed through Dewey is that the child may become attached to the teacher rather than to the process of learning. Dewey suggests that the relation to learning through an attachment to the teacher is external. Yet we have reformulated the child's need for acceptance by the teacher as conducive to learning because it presupposes an original respect for that which the child desires to know or to become, rather than what the child already believes or possesses, i.e., membership in the family. Yet, what growth or development must the child's attachment to the teacher undergo? In what way could the child's affection for the teacher be seen as an external relation to the piece of work to be done?

\section{Transforming Attachment: Resistance and Participation}

The child's interest in the teacher, then, may be formulated as a curiosity about the other's difference, and curiosity provides a way of referring to an immature interest. To be curious is to believe that there is something about the other which draws one to him. Curiosity tends to exclude the self's knowledge of its own participation in the formulation of the other as one who is attractive or desirable. Curiosity is often depicted as that impulse which gets children into trouble. The trouble is that the child is drawn to whatever calls her, and thus she has no way of limiting what calls through an understanding of her own participation in sounding the call. In Truffaut's film, Small Changes, a child is shown who first throws a kitten out a window and then who throws himself out the window because, it seems to the viewer, the possibility was simply there. The child saw a window and was drawn to experience the difference between being inside and outside of it. While, however, the one who is curious believes that the source of any interest lies outside the self, curiosity is also recognized as a quality that can be inhibited or frustrated by the absence of a supportive environment.

Jules Henry suggests that it is not curiosity but docility that animates the child's attachment to the teacher. According to Henry, the child who is 
motivated by the need for acceptance will subordinate her own will in order to please the teacher. A child may also fear that any failure to be obedient will result in the loss of the teacher's approval. Henry writes that through this desire for acceptance a child may become docile:

It should be pointed out that the mental docility (or near docility) achieved in these middle-class schoolrooms is a peculiar middle-class kind of docility. It is not based on authoritarian control backed by a fear of corporal punishment, but rather on fear of loss of love. More precisely, it rests on the need to bask in the sun of the teacher's acceptance... This kind of docility is more lethal than the other, for it does not breed rebellion and independence, as a struggle against authoritarian controls may, but rather a kind of cloying paralysis; a sweet imprisonment without pain. (1974, p. 175)

According to Henry's description, the child who is docile does not feel the pain of being a prisoner, but only the sweetness of imprisonment by that which is so desirable. The child finds herself captivated, enraptured, or enveloped by the teacher's difference, and at this point Henry fears that the child has lost all awareness of her subordination and of the need to rebel against this state.

Henry has chosen an interesting image, "sweet imprisonment," for the portrayal of docility. It suggests, for example, the power that the mythical Sirens had in Homer's Odyssey to make them forget the purpose or direction of their own life and to fall victim to the Siren's beautiful music. The inspiring ones, then, are not thought to impose their will upon others, but rather they take the others' will from them.

Is this not fanaticism that Henry fears? In Henry's depiction of docility the teacher dominates the child, whereas Henry implies that the child should free herself from such rule by controlling the educational experience by severing it from an attachment to the teacher. Henry then might interpret Dewey as recommending that autonomy for the student is only possible when the child makes her attraction to the teacher subject to the project of learning. In this view, learning is to be achieved apart from the child's relation to the teacher, this independence in learning would allow the child to limit the teacher's influence, and it is in this context that another stimulus must be found to motivate the child to learn.

What other view is possible of the child's need for acceptance? What alternative exists to the "sweet imprisonment without pain" besides freeing the child from the spell cast by the other? In an alternative approach we would continue to ask how could the child understand her need for acceptance by the teacher as originating in the sense of herself as a student? What place in the child's potential history as a theorist does the need for acceptance occupy? What relation could the child be invited to form to her affection for the teacher? The child could be invited to practice resistance to the teacher's attraction without disowning it. In order to practice resistance, the child would need to see that the desirability of the teacher is dependent upon the child's provision for what could be attractive or desirable. Odysseus told his men to tie him to the ship's mast when sailing past the Sirens in order that he could both listen and remain himself. This image can aid in the expression of the child's problem: What will serve to tie the child to himself, while at the same time she hearkens to the other? The strongest tie seems to be one that ties the desirability glimpsed in the 
teacher to the productivity of the student. While the child may be curious about the teacher's difference, curiosity needs to be recognized by the child as the immature form of an attachment. Whereas curiosity is the belief that one only follows the other's call, the process of learning involves understanding how one participates in generating that which could call one.

In this view, learning or development occurs through allowing the child to accept her initial impulse for the teacher's acceptance as an insight, concerning the teacher's difference from a parent, and yet as an immature form of the relation to the teacher. When the child is invited to reflect upon the need for acceptance within the educational context, then she also experiences a kind of freedom. She is free to translate her original need, to betray one version of what it could mean, i.e., docility, and to accept another. While at any given point a child may or may not realize the possibility for reflection inherent in the desire for approval, nevertheless, within the educational experience each child could be called upon to establish the dignity of her place in relation to the teacher. The teacher's work is to invite the child to include herself as a valued part of the relation to the teacher. The child is invited to enjoy the attachment to the teacher by understanding that the desirability of the teacher is a result of the productivity of the self, i.e., the child's production of the difference between home and school.

Dignity suggests that there is something irreducible about the character of one: there is something essential about oneself or another which must be respected. Similarly, there is something about the child's own history that must be respected. To invite the child to show resistance and reflect upon her own need for the teacher is to invite her to dignify her own history. The child needs to recollect the insight that is implied by the student's need for acceptance. Also, how might curiosity, an unaccountable attraction, be reconceived as a moment in the development of the self?

For Henry, the child must betray her feelings for the teacher in order to free herself from the use of these feelings by the teacher to control her. The alternative view of loyalty, however, would state the problem differently: we must betray what we cannot love; that is, we must betray what cannot call upon the self to display its preferences. In this view, the attractiveness of the teacher may be that the teacher can invite the child to enjoy the student's need for acceptance. Education here would arouse feeling for the attractiveness of the other. This feeling need not lead to subjugation through seduction, but rather it invites one to enter into discourse with another. More precisely, the other's presence itself is recognized as the result of a discourse involving the articulation of the self.

\section{Conclusion}

In conclusion, the question of how one teaches loyalty requires a consideration of situations in which loyalty may be at stake, and for the child loyalty may be at stake in the relation to the teacher. We have asked what is the importance of the child's attachment to the teacher? How does this attraction differ from the child's feelings for her family? What occasion 
does the attachment to the teacher provide for learning about loyalty? The complexity of the child's relation to the teacher reflects a complexity inherent in loyalty itself. It is suggested that the child should resist succumbing to the feelings of attraction by overlooking her own role in the production of the teacher's desirability, and the child should resist disowning or abandoning the attachment, as Henry suggests, because it excludes the teacher-student relation from examination and potential reformulation.

\section{References}

Dewey, J. (1975). Moral principles in education. Carbondale, Illinois: Southern Illinois University Press, 1909.

Dewey, J. (1978). The middle years, 1899-1924. Volume 5:1908. Carbondale, Illinois: Southern Illinois University Press.

Henry, J. (1974). Docility of giving teacher what she wants. In S. Fishman, A. M. Kazamias \& H. M. Kliebard (Eds.), Teacher, student and society, Boston: Little, Brown \& Company.

Homer. (1937). In W. H. D. Rouse (Trans.) The Odyssey. New York: The New American Library. 